\title{
Citizen Participation in E-Government Services Sri Lanka: Challenges and Opportunities
}

\author{
J.M. Shalani Dilinika ${ }^{1}$, Prof. M.K Weerasinghe ${ }^{2}$ \\ ${ }^{1,2}$ Department of Library and Information Science, University of Kelaniya, Sri Lanka
}

\begin{abstract}
Advancements in Information and Communication Technology (ICT) has affected the modern day activities in an unprecedented manner where it has changed the shape of countries, organizations, societies, services and lifestyles of people across the world. During the past few decades' societies have witnessed an enormous growth in the IT sector which has drastically changed the way people live today. According to that, information and communication technology for public administration has lead the way to e-government while providing an easy platform for all citizens to find information in an effective manner. In order to provide e-government services, Sri Lankan government has introduced "E- Sri Lanka National Development" project in the year of 2005 and Sri Lanka government web portal was the central place of that implementation. This study investigates the usage of e-government services among citizens of Sri Lanka. The research mainly focuses to identify the factors that can be impacted on the usage of e-government applications among citizens in Sri Lanka. Citizen's awareness levels, usage of different egovernment applications and attitudes on the use of e-government services were found in this study. Moreover, it was found that some major issues and challenges related to e-government services and suggestions were made to improve citizens' participation and usage of e-government services for better information dissemination and development of the country.
\end{abstract}

Keywords: Citizen; E-government; Government Information; ICT; Sri Lanka 